per volume. This, however, may possibly be reduced if sufficient applications follow the prospectus now issued. A specimen sheet indicates that each colour would be named, and referred also to the British Colour Council's classification, to the "Repertoire des Couleurs", and to the standards of Ridgway and Ostwald. A brief history of the name appears, horticultural examples are cited, and French, German, Italian and Spanish synonyms are given. The chart should have great utility, not only in the garden, but also wherever colours have to be compared with accuracy. A preliminary application form is now available, and those interested should communicate with the Royal Horticultural Society, Vincent Square, S.W.1. It is expected that the first volume will appear towards the end of 1936 or early in 1937.

\section{Medal Awards for Inventions}

THE Council of the Institute of Patentees has decided to suspend the award of the Institute Bronze Medal and in place thereof to substitute the Institute's Silver Medal to rank equally with the Founder's Silver Medal. These medals. will be awarded in each section of the Exhibition of Inventions to be opened in the Central Hall, Westminster, S.W.1 on September 30 and in Newcastle on November 25 ; therefore ten silver medals will be awarded throughout the five sub-sections of the New Inventions Section of the Exhibition. The Gold, Silver and Bronze Certificates will be awarded as in previous years. As the Institute proposes to organize a series of exhibitions throughout the country, it has been decided that the Grey-Wilson Memorial Gold Medal, supported by cash prize, together with the Yorkshire Medal, will be competed for during January of each year, the successful exhibitors at any Exhibition organized by the Institute being eligible to compete. The Yorkshire Medal is a new medal which was provided for under the will of the late Mr. Hoffman-Wood, an architect of Addingham, Yorkshire, who died three years ago, and the Institute will make recommendations annually to the trustees regarding its award. The medal is valued at twenty-five guineas, and sufficient funds are available for an award in perpetuity. The award of the Yorkshire Medal must be for an invention not relating to warfare.

\section{International Naval Architecture and Marine Engineering}

THE first international meeting of naval architects and marine engineers to be held in the United States takes place in New York on September 14-19, at which papers will be read dealing chiefly with safety of life at sea and large Atlantic liners. The Dominion of Canada, France, Germany, Great Britain, Italy, Japan, Spain and Sweden are sending delegations at the invitation of the Society of Naval Architects and Marine Engineers of New York. The British delegation, under the leadership of Lord Stonehaven, president of the Institution of Naval Architects, and Dr. J. T. Batey, president of the North-East Coast Institution of Engineers and Shipbuilders, will number about a hundred, including ladies, and will represent the Institution of Naval Architects, the
Institute of Marine Engineers, the Institution of Engineers and Shipbuilders in Scotland, and the North-East Coast Institution of Engineers and Shipbuilders.

\section{International Congress of the History of Science}

THE fourth International Congress of the History of Science will meet in Prague, in 1937, during the last week of September. The principal theme of the Congress will be "Science in the Eighteenth Century". The chairman of the Congress and of the Organizing Committee is Prof. Quido Vetter, the actual president of the International Academy of the History of Science. The announcement was made and discussed at the meeting of the Academy of the History of Science at Cluj (Rumania) in conjunction with the International Committee of Historians, in April last. During the meeting, several papers of great interest were read : (1) A. Mieli, "Our Present Knowledge of Arabian Science" ; (2) Prof. A. Reymond (Lausanne), "Occult Sciences and Exact Seience in Ancient Times" ; (3) Prof. A. Singh (Lucknow), "History of Trigonometry in India"; and (4) Prof. V. Bologa (Cluj), "Foreign Influences on Rumanian Medicine". In a business session of the meeting, Drs. Reymond, Ulrich, Sergescu, Singh and Greenwood read reports on the organization of the teaching of the history of science in their various countries. The "Chronological Repertory of the Exact Sciences during the Sixteenth Century" was adopted for publication as a special number of the Bulletin du Comité des Sciences Historiques.

\section{British School of Archæology at Athens}

IN October next the British School of Archæology at Athens will celebrate the fiftieth anniversary of its foundation. As part of the celebration an exhibition will be held at the Royal Academy of Arts, Burlington House, London, to illustrate the discoveries in Greece and Crete, which have resulted from the work of the School. A special section of the exhibition will be devoted to the Minoan civilizations of Greece and the excavations at Knossos, which were conducted by Sir Arthur Evans, honorary student of the School, and in which the architects of the School took part. This section of the exhibition is being prepared by Sir Arthur Evans himself, with the facilities given him by the authorities of the Ashmolean Museum, Oxford, to which the antiquities brought from Knossos by Sir Arthur were entrusted. It is understood that the exhibition will be inaugurated by H.R.H. the Duke of Kent on October I3, at 3 p.m., and will be open to the public from October 14 until November 14. The occasion of the jubilee of the School will also be marked by a special fund which it is proposed to raise to enable the School to increase its staff, improve its library and accommodation, and provide for the needs of the graduates who are sent to Greece in increasing numbers for advanced study by the universities.

\section{Congrès Préhistorique de France}

IT is announced that the twelfth session of the Congrès Préhistorique de France will be held at 
Toulouse on September 13-16 and continued at Foix on September 17-20. This is the third occasion only on which the Congress has met since the Great War, the meetings, held biennially between 1905 and 1913 , having been intermitted during and after the War until 1931. The coming session, which is the first to be held in the Pyrenean region, will afford members an opportunity to visit a number of famous and important archæological sites, such as Aurignac, Mas d'Azil, Marsoulas, Gargas, Niaux and Portel. Excursions to these are being arranged as part of the daily programme. As is usual in congresses of this character, a number of topics is suggested for the communications to be submitted. These include the earlier palæolithic of the area, the terraces of the Garonne and their quartzites, prehistoric art, the mesolithic and the neolithic periods, and artificial caves and subterranean refuges. Arrangements are being made by the local committees at Toulouse and Foix for a special exhibition of prehistoric finds from the excavations and collections of the archæologists of the two departments of Haute Garonne and Ariège. It is also to be noted that the Musée d'Histoire Naturelle de Toulouse has a collection of cave exhibits which is considered to be the finest in the whole of France. The Congress, of which M. le Comte $H$. Begouen will act as president, has the official support of the University of Toulouse, the municipal authorities of Toulouse and Foix, and the Departmental Councils of Haute Garonne and Ariège. Subscriptions (members, 30 francs; members receiving the report, 100 francs; associates, 20 francs) should be forwarded to the General Secretary and Treasurer, M. Ch. Schleicher, 9 rue de Verneuil, Paris (viie).

\section{Announcements}

Among the appointments and promotions in the Colonial Service recently announced are the following : C. C. Webster to be agricultural officer, Nigeria; D. A. B. Davies to be field geologist, British Guiana; H. A. Smith to be divisional engineer, Posts and Telegraphs Department, Nigeria; A. A. Strachan to be senior engineer, Posts and Telegraphs Department, Malaya.

ON August 14, M. Georges Détré, a French airman, established a new world altitude record of 14,836 metres $(48,674 \mathrm{ft}$.) at Villacoublay. According to the Paris correspondent of The Times, this figure exceeds by more than 400 metres $(1,749 \mathrm{ft}$.) the previous record set up by the Italian, Signor Donati, in April 1934. The machine used by M. Détré was a Potez 50 Special fitted with a Gnôme-et-Rhône $K .14$ engine.

The Council of the Iron and Steel Institute makes annually a limited number of grants from the research fund founded by the late Mr. Andrew Carnegie in aid of metallurgical research work. The object of the scheme is to enable qualified students to conduct researches on problems of practical and scientific importance relating to the metallurgy of iron and steel and allied subjects. Candidates, who must be less than thirty-five years of age, must apply before September 30, on a special form to be obtained from the Secretary of the Institute. The maximum amount granted in any one year will, as a rule, not exceed $£ 100$.

OF 2,590 offenders examined in the psychiatric clinic of the Court of General Sessions, New York, within the past year, less than 1 per cent were found to be definitely insane.

Dr. Maximulan Ehrexstein, research fellow in physiology, Department of Medicine, University of Virginia, has been awarded one of the prizes of the Van't Hoff Fund by the Royal Academy of Sciences of Amsterdam in recognition of his work on the alkaloids of tobacco and the catalytic dehydrogena. tion of cyclic bases.

WE have received from the City Librarian of Leeds eight bulletins or catalogues of technical engineering books. They are divided into the following eight groups: (1) mechanics and materials; (2) mechanical engineering; (3) workshop practice; (4) civil engineering; (5) mining engineering; (6) metallurgy and metal working; (7) electrical engineering-part I; (8) electrical engineeringpart II. Each of the catalogues is subdivided, so it is a very simple matter to find out the standard technological works dealing with a particular subject. The address is Leeds Public Libraries, Municipal Buildings.

In the letter "Anomalies in the Fine Structure of the First Spark Spectrum of Iodine" (NATuRE, June 20, p. 1030), the line $\lambda 4060 \cdot 2$ is said to consist of three components : 0.000 (4), +0.08I (3), $+0 \cdot 121(2) \mathrm{cm}^{-1}$. Dr. K. Murakawa informs us a mistake occurred in his manuscript ; this line should read : $0.000(2),+0.081(3),+0.121(4) \mathrm{cm}^{-1}$.

Applicatrons are invited for the following appointments, on or before the dates mentioned :

Temporary assistant civil engineers in the Air Ministry-The Secretary (W.B.9), Room 712, Adastral House, Kingsway, W.C.2 (August 22).

A part-time teacher of zoology-and/or biology in the Northern Polytechnic, Holloway, N.7-The Clerk (September 4).

An experimental assistant in a War Department establishment at Woolwich-The Superintendent, Signals Experimental Establishment, Woolwich Common, S.E.18 (September 4).

Junior scientific officers in the National Physical Laboratory, Teddington-The Director (September 15).

An instructor in electrical engineering in the Bulawayo Technical School-The Official Secretary, Office of the High Commissioner for Southern Rhodesia, Rhodesia House, 429 Strand, W.C.2 (September 19).

A professor of anatomy in the University of Manitoba-The Dean, Faculty of Medicine. 